\title{
Reconstruction of the Mining Policy Perspectives of Progressive Law
}

\author{
Faisal $^{1}$, Ndaru Satrio ${ }^{2}$, Andi Cery Kurnia ${ }^{3}$ \\ \{progresif_1shp@yahoo.com ${ }^{1}$, satrio.ndaru9@gmail.com ${ }^{2}$, andicery@gmail.com ${ }^{3}$ \} \\ Universitas Bangka Belitung, Indonesia ${ }^{1,2,3}$
}

\begin{abstract}
The mining sector is a reality that is always attractive to researchers conducting studies. In the field of criminal law, punishment is always oriented towards criminal sanctions. The most important part of the basic idea and purpose of punishment has often gone unnoticed by policy formulation. This is what sometimes makes criminal law enforcement lose its criminal philosophy orientation. So how important it is to reconstruct criminal policies, especially in the mining sector. The aim of this research is to restructure criminal policy through textual (legal) and contextual (mining reality) studies. The link between the two will be studied in a reflective and analytical manner. The research method uses socio-legal research. The results of the research study concluded that the design of criminalization policies in the mining sector must be built based on a scheme that is inseparable from social policy and criminal policy, Siskumnas, elaboration on the theoretical basis of the objectives of punishment, and based on a scientific approach. In the end, punishment will be born with a progressive legal dimension with a holistic paradigm and criminal law politics through policy design.
\end{abstract}

Keywords: Progressive Law, Criminal Policy, Mining, Reconstruction

\section{Introduction}

The existence of abundant natural resources, minerals and coal must be preserved and well managed as a form of accountability to the Lord yme for his bounty. The basic principles and principles for managing our natural resources are found in chapter 33 verses (3) the national republic of Indonesia 1945. That the earth, the water and the natural resources it contains are controlled by the state and used for the greatest of people's prosperity. The deep significance found in the chapter is notable for the state organizers to carry out their activities on the management of natural resources, including the management of mineral and coal mines. The right of state ruling over the mineral and coal gives the state a mandate to perform policies (beleid) and stewardship (bestuursdaad), regelendaad (regelendaad), processing (beheersdaad), and supervision (toezichthoundensdaad) for the greatest cause of people's prosperity. The use of the word "for the greatest measure of people's prosperity" meant a central purpose that was to be embodied in the exercise of the natural resources of sustainable prosperity. It must not be misunderstood or even distorted for the benefit of some groups. Because rulers often use a particular momentum to put their own interests first. Nina Indriati Lestari in her paper governance, conflicts and rights: case studies on the informa. 
“Through the country's mining law and government decrees, these 'controlling' and 'exploiting' aspects often manifest themselves in the granting of mining permits to selective big companies and in the prioritising of their investments and interests" $[1]$.

Following the issuance of the Minerba Law, the central government was given the mandate and authority to restructure mining management. We know that the most recent mining regulation is Law Number 3 of 2020 concerning Amendments to Law Number 4 of 2009 concerning Mineral and Coal Mining. According to the author, there are quite a lot of criminal provisions in it. The first is Article 158 of Law Number 3 of 2020 concerning Amendment on Law Number 4 of 2009 concerning Mineral and Coal Mining. This article contains criminal provisions related to licensing.

Other criminal provisions are contained in Article 159 of Law Number 3 of 2020 concerning Amendments to Law Number 4 of 2009 concerning Mineral and Coal Mining. The offense in this article is related to submitting false reports and false information. Criminal provisions related to the use of permits that are not in accordance with their designation are contained in Article 160 of Law Number 3 of 2020 concerning Amendments to Law Number 4 of 2009 concerning Mineral and Coal Mining.

Further criminal provisions related to the smuggling of the transportation and sale of mineral and coal, as well as the criminal act of processing mineral and coal without rights. The provisions for the offense are contained in Article 161 of Law Number 3 of 2020 concerning Amendments to Law Number 4 of 2009 concerning Mineral and Coal Mining. Another criminal provision is related to not carrying out post-mining reclamation and not providing post-mining reclamation guarantee funds. This provision is contained in Article $161 \mathrm{~B}$ paragraph (1) of Law Number 3 of 2020 concerning Amendments to Law Number 4 of 2009 concerning Mineral and Coal Mining. Other criminal provisions are contained in Article 162 of Law Number 3 of 2020 concerning Amendments to Law Number 4 of 2009 concerning Mineral and Coal Mining. The above offense is related to obstructing mining business activities. Further criminal provisions in Article 163 of Law Number 3 of 2020 concerning Amendments to Law Number 4 of 2009 concerning Mineral and Coal Mining. This article regulates the provisions for criminal offenses committed by corporations. Finally, the criminal provisions related to additional crimes contained in Law Number 3 of 2020 concerning Amendments to Law Number 4 of 2009 concerning Mineral and Coal Mining.

Understanding carefully the criminal provisions contained in Law Number 3 of 2020 concerning Amendments to Law Number 4 of 2009 concerning Mineral and Coal Mining, we can underline that punishment which is attempted as a stimulant to improve the situation always and always prioritizes criminal sanctions. It is important to note that the basic idea and purpose of punishment must always be held firmly. Do not let this most important part escape the attention of the formulation policies.

The urgency is very clear, namely that efforts to restructure criminalization policies through textual (legal) and contextual (mining reality) studies must be encouraged. Not only from the perspective of understanding the law, but in real terms we must also be able to measure how effectively the legal policies issued by the authorities can overcome the existing problems. The study explored by the author in a focused manner is related to the design of criminal policies in the mining sector with a progressive legal perspective. 


\section{Research Method}

The research method uses socio-legal research. Articles in laws and regulations and policies can be analyzed critically and their meaning and implications for legal subjects can be explained. In this case reviewing Law Number 3 of 2020 concerning Amendments to Law Number 4 of 2009 concerning Mineral and Coal Mining and its influence in society [2].

\section{Results and Discussion}

\subsection{Design of Criminal Policy in Law Number 3 of 2020 concerning Amendments to Law Number 4 of 2009 concerning Mineral and Coal Mining}

Law Number 3 of 2020 concerning Amendments to Law Number 4 of 2009 concerning Mineral and Coal Mining, the authors admit, cannot be separated from administrative law. The reason is quite clear, namely, of the various articles in this regulation, the issue of permission has caught the attention of the author. Even Barda Nawawi Arief in his book Kapita Selekta Hukum Pidana, it can be said that administrative criminal law is essentially an embodiment of criminal law policy as a means of enforcing or implementing administrative law.

Practically and logically the author tries to focus on discussions related to his criminal policy. It has been stated at the beginning of several articles that contain criminal provisions. The author tries to examine them one by one. Starting from Article 158 of Law Number 3 of 2020 concerning Amendments to Law Number 4 of 2009 concerning Mineral and Coal Mining. The penalty is imprisonment for a maximum of 5 years and a maximum fine of 100 billion Rupiah. Second, Article 159 of Law Number 3 of 2020 concerning Amendments to Law Number 4 of 2009 concerning Mineral and Coal Mining. The criminal sanction is a maximum imprisonment of 5 years and a maximum fine of 100 billion Rupiah. Third, Article 160 of Law Number 3 of 2020 concerning Amendments to Law Number 4 of 2009 concerning Mineral and Coal Mining.

The criminal sanctions are imprisonment for a maximum of 5 years and a maximum fine of 100 billion Rupiah. Fourth, Article 161 of Law Number 3 of 2020 concerning Amendments to Law Number 4 of 2009 concerning Mineral and Coal Mining. 105. The criminal sanction in this article is imprisonment for a maximum of 5 years and a maximum fine of 100 billion Rupiah. Fifth, Article 161 A of Law Number 3 of 2020 concerning Amendments to Law Number 4 of 2009 concerning Mineral and Coal Mining. The criminal sanction is imprisonment for a maximum of 2 years and a maximum fine of 5 billion Rupiah. Sixth, Article 161 B paragraph (1) of Law Number 3 of 2020 concerning Amendments to Law Number 4 of 2009 concerning Mineral and Coal Mining. The criminal sanction is a maximum imprisonment of 5 years and a maximum fine of 100 billion Rupiah. Seventh, 162 of Law Number 3 of 2020 concerning Amendments to Law Number 4 of 2009 concerning Mineral and Coal Mining. The criminal sanction in this article is a maximum imprisonment of 1 year and a maximum fine of 100 million Rupiah. Eighth, Article 163 of Law Number 3 of 2020 concerning Amendments to Law Number 4 of 2009 concerning Mineral and Coal Mining. The criminal sanction is a fine with an additional weight of $1 / 3$ (one third) of the maximum penalty imposed.

Based on the explanation above, we can trace the design of the criminal policy through the criminal system which includes: (1) type of crime (strafsoort), (2) serious/light punishment (strafmaat), (3) how to carry out the crime (strafmodus). The types of criminal sanctions 
contained in the mineral and coal regulations are not much different from those contained in the Criminal Code. The reason is that this regulation uses the same sanctions, namely the main and additional penalties. Regarding the severity of the existing criminal sanctions, the mineral and coal regulations provide a general maximum threat in the provisions of criminal sanctions. This gives the judge the freedom to give his verdict to the accused. The method of carrying out crimes contained in the mineral and coal regulations is also not regulated in detail. When this happens, the provisions used will still be returned using the main criminal law.

\subsection{Criminal Policy Design in Mineral and Coal Mining Regulation Based on Progressive Law}

Policies or efforts to tackle the problem of crime are essentially an integral part of community protection efforts (social defense) to achieve social welfare (social welfare). Therefore, it can be said that the ultimate goal of criminal policy is "protection of society" to achieve the main goal which is often referred to by various terms, such as "happiness of the citizen" (happiness of the citizen); "A healthy and refreshing cultural life" (a wholesome and cultural living); "Social welfare" or to achieve "balance" (equality). This is in line with the concept developed by progressive law. The basic philosophy of progressive law is an institution that aims to lead people to a just, prosperous life and make humans happy [3].

In the Criminal Code, to be precise in Article 10 of the Criminal Code, there are two types of criminal sanctions, namely primary and additional penalties. The main penalties are capital punishment, imprisonment, imprisonment, and fines and imprisonment as contained in Law No. 2 of 1946 concerning closure. Additional punishments are in the form of revocation of certain rights, confiscation of certain items and announcement of a judge's decision. Laws that contain criminal provisions are mostly administrative criminal laws (administrative criminal law). The criminal provisions in the Minerba Law are not much different from those contained in the Criminal Code. What makes it different is that there is no death penalty in it. However, what needs to be a common concern is that the criminal provisions in mining management regulations only provide assistance to administrative law, but seem to rely on criminal law enforcement. Especially if you look at the nature of this criminal law naturally, it should be enforced when other branches of law are unable to solve their problems. One of the evidences that can be stated is that if the Minerba Law is seen as a system, with the introduction of Chapter XXII regarding Administrative Sanctions previously the criminal rules contained in Chapter XXIII regarding Criminal Provisions, this shows that administrative sanctions take precedence first and then criminal sanctions [4].

The awareness to pay more attention to the existence of the community around the mining business has actually begun to be realized by various parties, including the entrepreneurs themselves. As stated by Sara Bice in the Willemien du Plessis article entitled Responsible Mining: Key Principles for Industry Integrity by Sara Bice. He said that:

"There is a realisation that mining should not only protect the natural environment but also contribute to the upliftment of the surrounding communities and the communities from whence their workers originate (the sending communities)" [5].

Mining businesses must provide economic and social benefits, as well as accelerate regional development and encourage community/small and medium-sized business/entrepreneur economic activities as well as encourage the growth of mining supporting industries [6]. Seeing some Indonesian people who still depend a lot on their lives through their mining business, the 
author thinks that the criminal sanctions that are being threatened should be based on the real situation on the ground. This is done to minimize the issuance of judges' decisions that do not reflect justice in society if they only see it from a textual point of view without seeing the contextual. Regulations that include a general minimum limit are also very necessary, so that judges as determinants of a decision will be easier and more balanced in determining criminal sanctions. Sudarto stated that criminalization is defined as the process of determining an act as an act that can be punished. This process ends with the formation of a law in which the act is punishable by a criminal sanction [7].

The way of carrying out crimes in the mineral and coal regulations that we know is not regulated in detail. This situation should be covered by implementing regulations, so that it will make it easier for law enforcement officers at each stage of the examination to apply the law. Especially with regard to fines, if there is no clear regulation about the criminal sanctions being threatened, it will certainly be useless because it is ineffective and efficient.

Based on the analysis of the main issues of criminal law in Law Number 3 of 2020 concerning Amendments to Law Number 4 of 2009 concerning Mineral and Coal Mining which are based on progressive law, it is hoped that there will be improvements related to criminal sanctions which of course are adjusted to the analytical knife used by the author that is based on progressive law. The reconstruction of criminal sanctions carried out in principle are: (1) The existing formulation of criminal sanctions should be adjusted to the actions, so that a balance will be realized; (2) The formulation of the criminal sanction must be clear and intact, especially in relation to the way the punishment is executed.

Everything must be returned to its original destination. If we look back at Barda Nawawi Arief's opinion in his book entitled Purpose and Guidelines for Criminalization (Perspective of Criminal Law Reform and Comparative Perspective) that:

"The formulation of the objectives and guidelines for punishment is intended as a function of controlling/controlling/directing and at the same time providing a philosophical basis/foundation, rationality, motivation and justification for punishment" [8].

So in principle, law must be able to be a clear solution to the problems experienced by humans, not that humans are sacrificed for the law itself.

\section{Conclusion}

The design of the criminalization policy of Law Number 3 of 2020 concerning Amendments to Law Number 4 of 2009 concerning Mineral and Coal Mining can be traced through a criminal system which includes: (1) type of crime (strafsoort), (2) serious/light penalties (strafmaat), (3) how to carry out the crime (strafmodus). The types of criminal sanctions contained in the mineral and coal regulations are not much different from those contained in the Criminal Code. The reason is that this regulation uses the same sanctions, namely the main and additional penalties. Regarding the severity of the existing criminal sanctions, the mineral and coal regulations provide a general maximum threat in the provisions of criminal sanctions. This gives the judge the freedom to give his verdict to the accused. The method of implementing the crime contained in the mineral and coal regulations also does not regulate in detail. 
Based on the analysis of the main issues of criminal law in Law Number 3 of 2020 concerning Amendments to Law Number 4 of 2009 concerning Mineral and Coal Mining which are based on progressive law, it is hoped that there will be improvements related to criminal sanctions which of course are adjusted to the analytical knife used by the author that is based on progressive law. The reconstruction of criminal sanctions carried out in principle are: (1) The existing formulation of criminal sanctions should be adjusted to the actions, so that a balance will be realized; (2) The formulation of the criminal sanction must be clear and intact, especially in relation to the way the punishment is executed.

\section{Acknowledgement}

Praise and gratitude for God Almighty's presence for His blessings and mercy, the author, can complete this research. On this occasion, the authors express their gratitude for the support that has been given in doing research. We want to thank:

a. Prof. Esmi Warassih Pudjirahayu as one of the mentors in the many studies we have done;

b. Dr. Hotma P. Sibuea, S.H., MH, as one of the mentors in the many studies we have done;

c. Our family always provides support and prayers in every activity we do.

\section{References}

[1] N. I. Lestari, "Mineral governance, conflicts and rights: Case studies on the informal mining of gold, tin and coal in Indonesia," Bull. Indones. Econ. Stud., vol. 49, no. 2, pp. 239-240, 2013.

[2] E. Pranoto, "Kajian Sosio Legal Pengesahan Undang-Undang Organisasi Kemasyarakatan," J. Spektrum Huk., vol. 17, no. 1, pp. 84-92, 2020.

[3] Mukhidin, "Hukum Progresif Sebagai Solusi Hukum Yang Mensejahterakan Rakyat," $J$. Pembaharuan Huk., vol. 1, no. 3, 2014.

[4] U. Setiyahadi, "Kebijakan Hukum Pidana terhadap Tindak Pidana Pertambangan Mineral dan Batubara (Studi Kasus Normalisasi Kali Bebeng Kabupaten Magelang)." Fakultas Hukum UNISSULA, 2017.

[5] S. Bice, Responsible mining: Key principles for industry integrity. Routledge, 2016.

[6] W. Nugroho, I. Imamulhadi, B. D. Nugroho, and I. Nurlinda, "Kebijakan Pengelolaan Tambang dan Masyarakat Hukum Adat yang Berkeadilan Ekologis," J. Konstitusi, vol. 15, no. 4, pp. 816$835,2019$.

[7] L. S. Widayati, "Kebijakan Kriminalisasi Kesusilaan Dalam Rancangan Undang-Undang Tentang Hukum Pidana Dari Perspektif Moral (Criminalization Of Decency In The Criminal Code Bill From Moral Perspectives)," Negara Huk. Membangun Huk. Untuk Keadilan Dan Kesejaht., vol. 9, pp. 181-198, 2019.

[8] N. D. Irmawanti and B. N. Arief, "Urgensi Tujuan Dan Pedoman Pemidanaan Dalam Rangka Pembaharuan Sistem Pemidanaan Hukum Pidana,” J. Pembang. Huk. Indones., vol. 3, no. 2, pp. 217-227, 2021. 